\title{
Dünya Pamuk Tarımı ve Ekonomiye Katkı1s
}

\author{
Dilek TOKEL ${ }^{1}$ \\ $\ddot{O} z$
}

Pamuk bitkisi, geniş kullanım alanları, oluşturduğu katma değer ve istihdam olanakları ile yetiştirildiği yörelerin ve ülkelerin ekonomisine olumlu katkılar sağlamaktadır. Dünya pamuk ticaretine bakıldığında, 2020/21 itibarı ile Hindistan, ABD, Çin, Pakistan ve Brezilya gibi birkaç büyük üretici toplam dünya ihracatının yaklaşık yüzde 70'ini gerçekleştirmektedir. Bununla birlikte uluslararası pamuk ticaretini belirli hükümlerle disiplin altına almaya çalışan Dünya Ticaret Örgütü (DTÖ) üyesi $A B D$ ve $A B$ ülkeleri gibi ülkeler ve Çin, kendi çiftçilerini korumak üzere ekonomik ve siyasi güce dayalı politika araçları geliştirebilmektedirler. Bu durumda, gelişmiş ülkelerin uyguladıkları yüksek zirai sübvansiyonlar, dünya pamuk fiyatlarını baskılamakta ve dünya pamuk pazarında yeni yeni yer almaya çalışan, ancak ağır ekonomik koşullar altında bulunan Afrika ülkeleri gibi az gelişmiş ülkelerde pamuk üreticilerinin durumunu daha da zorlaştırmaktadır. Son olarak küresel ölçekte yaşanan Covid-19 salgını da, dünya genelinde ekonominin her alanında olduğu gibi pamuk tarımı ve ekonomisini de olumsuz etkilemektedir ve önümüzdeki birkaç yıl içinde bu olumsuz etkinin devam edeceği düşünülmektedir. Bu çalışmada, pamuk bitkisi ve tarımı hakkındaki genel bilgilere ek olarak, dünya pamuk tarımı ve ekonomisi ile ilgili bazı son dönem verileri paylaşılmış, dünya genelinde pamuk ticareti, organik ve genetiği değiştirilmiş pamuk üretimi ile Covid-19 salgınının pamuk ekonomisine etkileri tartışılmışır.

Anabtar Kelimeler: Gossypium hirsutum L., Pamuk Fiyatları, Pamuk Ticareti, Organik Pamuk, Genetiği Değiştirilmiş Pamuk, Covid-19

\section{World Cotton Agriculture and Its Contribution to Economy}

\begin{abstract}
Cotton plant makes a positive contribution to the economies of the regions and countries it is grown, through its wide range of uses, value added and employment opportunities. Looking at the global cotton trade for 2020/21, several large producers such as India, United States, China, Pakistan and Brazil produced for about 70 percent of total world exports. However, member countries of the World Trade Organization (WTO) such as the US, EU countries and China, which try to discipline the international cotton trade through specific regulations, can develop policy instruments based on economic and political power to protect their farmers. In this case, high agricultural subsidies applied by developed countries suppress world cotton prices and impede the position of cotton producers in less developed countries, such as African countries that are trying to take a new place in the global cotton market, but are in dire economic straits. Finally, the global Covid-19 epidemic also affects the agriculture and cotton economy as well as all sectors of the economy around the world, and this negative impact is believed to continue over the next few years. This study, in addition to general information on cotton crops and agriculture, provided some recent data on the global cotton agriculture and economy, cotton trade, organic and genetically modified cotton production, and the impact of the Covid-19 epidemic on the cotton economy.
\end{abstract}

Key Words: Gossypium hirsutum L., Cotton Prices, Cotton Trade, Organic Cotton, Genetically Modified Cotton, Covid-19

\section{Atıf İçin / Please Cite As:}

Tokel, D. (2021). Dünya pamuk tarımı ve ekonomiye katkısı. Manas Sosyal Araştırmalar Dergisi, 10(2), 1022-1037.

Geliş Tarihi / Received Date: 17.01.2021

Kabul Tarihi / Accepted Date: 02.04.2021

\footnotetext{
${ }^{1}$ Marmara Üniversitesi, İktisat Fakültesi, İktisat Bölümü, dozyigit@marmara.edu.tr 


\section{Pamuk Hakkında Genel Bilgiler}

Ebegümecigiller (Malvaceae) ailesinin önemli bir üyesi olan pamuk (Gossypium birsutum L.) bitkisi, ılıman ve tropik bölgelerdeki 100'e yakın ülkede yaygın olarak yetiştirilen en önemli lif bitkilerinden biridir. Yeterli nemin olduğu sıcak iklimleri seven pamuğun başlıca yetiştiği yerler ABD, Avustralya, Çin, Hindistan, bazı Afrika ülkeleri ve Orta Doğu'nun belli bölgeleridir (Datta, Ullah, Ferdous, Santiago-Arenas ve Attia, 2020, s. 47; Ozyigit ve Gozukirmizi, 2009, s. 527; USDA, 2020a, s. 5).

Pamuk, yaygın ve zorunlu kullanım alanları ile insanlık için büyük ekonomik öneme sahip, üreticisi olan ülkeler için katma değer ve istihdam yaratan bir üründür (Majumdar, Singh ve Shukla, 2020, s. 145; Rehman, Jingdong, Chandio, Hussain, Wagan ve Memon, 2019, s. 49). Hammadde olarak pamuk, işleme uygulamaları ile çırçır endüstrisi, liflerinin kullanımıyla tekstil endüstrisi, tohumunun kullanılmasıyla yağ ve yem endüstrisi, linterinin kullanılmasıyla da kâğıt endüstrisi gibi birçok endüstri tarafından kullanılmaktadır (Munir, Rasul, Ahmad, Sajid, Ayub, Arif, Iqbal, Khan, Fatima, Ahmad ve Khan, 2020, s. 630; Ozyigit, 2009, s. 74). Petrol bazlı yakıta alternatif olarak pamuk tohumundan elde edilen yağ ise biyodizel üretiminde hammadde olarak gün geçtikçe daha fazla kullanılmaktadır (Sharma, Kodgire ve Kachhwaha, 2020, s. 1; Sundar ve Udayakumar, 2020, s. 795).

Diğer tarla bitkilerinin çoğunda olduğu gibi pamuk üretiminde asıl amaç, birim alandan en yüksek verimi elde etmektir. Bu nedenle pamuk sslah araştırmaları, yüksek biyokütle eldesine ilaveten yüksek lif kalitesi ve verimi, yüksek çıç̧ır randımanı, biyotik (böcek istilası, virüs ve mantar enfeksiyonları) ve abiyotik (kuraklık, tuzluluk, düşük veya yüksek sıcaklıklar, kirleticiler vb.) stres koşullarına ve tarım ilaçlarına toleranslı/dirençli ve hızlı büyüme yeteneğine sahip pamuk çeşitleri üretmeye odaklanmaktadır (Chohan, Perveen, Abid, Tahir ve Sajid, 2020, s. 240; Gao, Long, Tian, Jin, Liu, Zhang, Xu ve Song, 2016, s. 2; Hocaoglu-Ozyigit, Ucar, Altay ve Ozyigit, 2020, s. 2; Rauf, Shehzad, Al-Khayri, Imran ve Noorka, 2019, s. 30). Bununla birlikte, geleneksel yöntemlerin kullanıldığı eski moda 1slah yöntemleriyle geçmişte pamuk 1slahı yavaş ve elde edilen sonuçlar daha belirsiz olmuştur (Hayat, Bardak, Parlak, Ashraf, Imran, Haq, Mian, Mehmood ve Akhtar, 2020, s. 516). Pamukta geleneksel yöntemler yerine biyoteknolojik yaklaşımların kullanılması, zamandan tasarruf etmek ve istenen özelliklerdeki bitkileri elde etmek için büyük bir avantaj sağlamıştır (Ozyigit, 2009, s. 74). Modern bitki biyoteknolojisi, bitki doku kültürlerinin kurulmasını ve bitki 1slahı için istenen özellikleri içeren genlerin bitkilere transferi aşamalarını içerir (Ozyigit ve Gozukirmizi, 2008, s. 1665). Pamukta ilk başarılı doku kültürü çalısmaları 80’li yılların ortalarında Davidonis ve Hamilton (1983, s. 90-92)'un kalluslardan indirekt somatik embriyogenez ile bitki elde etmesi ile başlamış, günümüze kadar oldukça başarılı doku kültürü ve gen aktarımı çalışmaları yapılmış ve pamuğun biyoteknolojik 1slahında büyük yol kat edilmiştir.

Bununla birlikte son dönemlerde, dünya pamuk üreticileri için ekonomik anlamda karlllı̆̆ın azalması, tarımda enerji kullanımının artması, sera gazı emisyonları, kuraklık, tuzluluk, su miktarı ve kalitesinin azalması, pestisit kullanımı ve transgenik tohumların dünya üzerinde kontrolsüz kullanımı dâhil olmak üzere birçok ortak tehdit vardır (Dai ve Dong, 2014, s. 100; Küçük, 2015, s. 83-84). Ayrıca, küresel iklim değişikliği gibi faktörlerin yanı sıra, dünya genelinde ortalama sıcaklıkların zaman içinde artması, sıcaklık ve yağışların olumsuz bölgesel etkileri, özellikle tarımsal üretim faaliyetlerinin bu değişime adaptasyonu noktasında ciddi riskler ortaya çıkmaktadır (Gustafson, Collins, Fry, Smith, Matlock, Zilberman, Shryock, Doan ve Ramsey, 2014, s. 146; Li, Lin, Wang, Li, Liu, Chen ve Hu, 2020, s. 1-2; Malcolm, Marshall, Aillery, Heisey, Livingston ve Dayrubenstein, 2012, s. 1). Yine de, dünya genelinde pamuk ekimi uzun zamandan beri yapılmakta ve pamuk asla vazgeçilemeyecek bir ticari ürün olarak önemini korumaktadır.

USDA (Amerika Birleşik Devletleri Tarım Bakanlığı) tarafindan 2020 Aralık ayında yayınlanan ve dünya çapında pamuk verilerini içeren rapora göre, ülkelerin pamuk üretimi (bin metrik ton olarak) Çin (5.987), Hindistan (6.423), ABD (3.473), Brezilya (2.613), Pakistan (980) ve Özbekistan (762) şeklinde olmuştur (USDA, 2020a, s. 7). Bu durum bize, dünya genelinde pamuk bitkisinin ve lifinin vazgeçilmeyecek önemini ve dünya ekonomisindeki yerini göstermektedir.

Bu çalışmada, pamuk hakkında genel bilgilere ilaveten dünya pamuk tarımı ve ekonomisi ile ilgili bazı son dönem veriler paylaşılmış, dünya genelinde pamuk ticareti, organik pamuk üretimi, genetiği değiştirilmiş pamuk üretimi ve Covid-19 salgınının pamuk ekonomisine etkileri tartışılmışıır. 


\section{Dünya Pamuk Tarımı ve Ekonomisi ile İlgili Bazı Veriler}

Pamuk bitkisi, dünyada üretilen liflerin yaklaşık \% 35'ini sağlamaktadır ve bu anlamda tekstil endüstrisinde kullanılan en önemli bitkilerden biridir (Gündüz, Özlem, Gündüz ve Dölekoğlu, 2020, s. 550). Uzun yıllar boyunca dünya pamuk ekim alanlarında Çin başı çekmekteyken son yıllarda Hindistan ve ABD Çin'i geride bırakmıştır. Pamuk üretiminde ise sıralama Hindistan, Çin ve ABD şeklinde olmuştur. Ancak bugün $\mathrm{ABD}$, dünyadaki pamuk ihracatının neredeyse üçte birini yapmaktadır ve bu alanda lider konumdadir (Ugurlu, 2020, s. 207; USDA, 2020a, s. 9).

Ülkeler bazında pamuğun GSYİH (Gayri Safi Yurt İçi Hasıla)'ya olan katkılarına bakıldığında, özellikle sanayileşmiş ülkelerdeki ekonomik faaliyetin küçük bir bileşeni olduğu ve toplam ticaretin yalnızca \% 0,12'sini oluşturduğu görülmektedir. Ancak pamuk üretimi, Batı ve Orta Afrika'daki bazı az gelişmiş ülkelerde önemli bir rol oynamaktadır. Benin, Burkina Faso, Çad, Mali ve Togo gibi ülkelerde pamuk GSYIHH'nın \% 5-10'unu, toplam ihracat gelirlerinin üçte birinden fazlasını ve tarımsal ihracatın üçte ikisinden fazlasını oluşturmaktadır. Afrika'nın önemli pamuk üreticileri arasında yer alan ve gelişmekte olan ülkeler sınıfına giren Fildişi Sahili ve Kamerun'da ise pamuk üretimi GSYİH'nın sırasıyla \% 1,7'sini ve \% 1,3’ünü oluşturmaktadır. Pamuk, aynı zamanda, Afrika dışındaki gelişmekte olan bazı ülkeler için toplam ihracatın önemli bir bileşenidir. Özbekistan, Tacikistan ve Türkmenistan'daki pamuk ihracatı, toplam emtia ihracatının sırasıyla \% 45, \% 20 ve \% 15'ini oluşturmakta ve bu ülkelerde GSYİH'ya önemli bir katkı sağlamaktadır (Özbekistan'da \% 8 ve Tacikistan'da \% 8,2; Türkmenistan'da \% 4). Diğer ülkelere bakıldığında; yaklaşık beş milyon çiftçiden bir milyonunun üç milyon hektarlık bir alanda pamuk yetiştirdiği Pakistan'da pamuk üretimi GSYIH'ya \%10 katkıda bulunmaktadır. Pamuk, Türkiye'nin genel tarım sektörünün önemli bir bölümünü temsil etmektedir. Türkiye'de lif pamuk üretimi GSYIH'n'nn yaklaşık \% 1'ini ve toplam endüstri bitkileri üretiminin \% 5 'ini oluşturmaktadır. Dünyanın en büyük lif pamuk üreticisi olan Çin ve Hindistan için oldukça önemli endüstri bitkilerinden biri olan pamuk bu iki ülkede GSYİH'nın \% 1'ini oluşturmaktadır. Brezilya'da pamuk üretimi GSYİH'nın \% 0,2'sini oluştururken sektörde daralmanın yaşandığı Arjantin'de ise GSYİH'nın sadece \% 0,03’ünü oluşturmaktadır (Gillson, Poulton, Balcombe ve Page, 2004, s 3).

\section{Dünya Pamuk Ekim Alanları}

Tablo 1'de de görüldüğü gibi 2019-20 döneminde dünyada 34.840 bin hektarlık bir alanda pamuk ekimi yapılmış ve bu ekimin yaklaşık \% 35’i 13.300 bin hektarlık ekim alanı ile Hindistan'da gerçekleşmiştir. Hindistan'1 4.700 bin hektar ekim alanı ile ABD ve sonrasında 3.450 bin hektar ile Çin takip etmiştir. Pakistan 2.450 bin hektarla 4. sırada yer alırken Brezilya 1.670 bin hektarlık ekim alanı ile 5 . olmuştur. Son yıllarda özellikle Afrika ülkelerinde pamuk ekim alanlarının hacminin genişlemesi sonucunda Mali, Burkina Faso ve Benin gibi ülkeler dünya pamuk üretiminde söz sahibi hale gelmiştir.

Tablo 1. Dünya Pamuk Ekim Alanı (Bin Ha)

\begin{tabular}{ccccccc}
\hline Sira & Ülke & 2016/2017 & 2017/2018 & 2018/2019 & 2019/2020 & 2020/2021 \\
\hline $\mathbf{1}$ & Hindistan & 10.845 & 12.235 & 12.600 & 13.300 & 13.400 \\
$\mathbf{2}$ & ABD & 3.848 & 4.492 & 4.130 & 4.700 & 3.640 \\
$\mathbf{3}$ & Çin & 3.100 & 3.350 & 3.367 & 3.450 & 3.250 \\
$\mathbf{4}$ & Pakistan & 2.496 & 2.665 & 2.325 & 2.450 & 2.200 \\
$\mathbf{5}$ & Brezilya & 939 & 1.175 & 1.618 & 1.670 & 1.550 \\
$\mathbf{6}$ & Özbekistan & 1.250 & 1.208 & 1.100 & 1.010 & 980 \\
$\mathbf{7}$ & Mali & 656 & 704 & 730 & 740 & 200 \\
$\mathbf{8}$ & Burkina Faso & 740 & 879 & 646 & 580 & 550 \\
$\mathbf{9}$ & Benin & 418 & 530 & 656 & 670 & 600 \\
$\mathbf{1 0}$ & Türkmenistan & 545 & 545 & 534 & 550 & 600 \\
$\mathbf{1 1}$ & Türkiye & 420 & 462 & 520 & 570 & 350 \\
& Diğer & 4.610 & 4.950 & 4.992 & 5.150 & 5.190 \\
\hline
\end{tabular}

Kaynaklar: Pamuk Raporu, 2020, s. 2; USDA, 2020a, s. 9.

2020-21 dönemi dünya pamuk ekim alanlarına bakıldığında ise 34.840 bin hektarlık değerin 32.510 bin hektara gerilediği görülmektedir. Her ne kadar dünya pamuk ekim alanı sıralamasında bir değişiklik olmasa da, Hindistan hariç tüm ülkelerde pamuk ekim alanlarında bir önceki döneme kıyasla bir azalma olduğu görülmüștür. Tablo 1'de de görüldügüu üzere (bin hektar cinsinden) değerler Hindistan'da 13.400, ABD'de 3.640, Çin'de 3.250, Pakistan'da 2.200 ve Brezilya'da 1.550 şeklinde olmuştur. 
Bu düşüşün en önemli sebeplerinden birinin Covid-19 salgını olduğu düşünülmektedir. Bilindiği gibi, Covid-19 salgını, dünya genelinde tüm ekonomik dengeleri sarstığı gibi tarımsal uygulamaları da olumsuz anlamda etkilemektedir. Dünya Sağlık Örgütü (WHO)'nün de hastalık önleme stratejisi olarak "evde kal" sloganını salık vermesi pamuk ile ilgili tarımsal faaliyetleri de etkileyerek pamuk tarımı ve ticareti ile ilgili verileri düşürmüştür (Genc, 2020, s. 72). Ayrıca, Covid-19 salgını sonucu pirinç, tahıllar, mercimek ve nohut gibi temel gıda maddelerinin fiyatlarında görülen artışlar nedeniyle pamuk eken çiftçilerin bu tür ürünlere yönelmeleri de ekiminde kullanılan arazi hacminde önemli düşüşlere neden olmuştur (Organic Cotton Market Report, 2020, s. 57).

\section{Dünya Lif Pamuk Üretimi}

Dünya lif pamuk üretimi verilerine bakıldığında, 2019-20 döneminde bir önceki ylla göre yaklaşı \% 1'lik bir artısla değerin 25.686 bin tondan 25.929 bin tona ulaştığı, ancak 2020-21 döneminde ise hafif bir azalma ile 24.800 bin tona düştüğü görülmektedir (Tablo 2). 2019-20 döneminde Hindistan Çin’i geçerek 6.423 bin ton üretim ile birinciliğe yükselmiş ve dünya lif pamuk üretiminin \% 23 'üni karşılamıştır. Hindistan'1 5.933 bin ton ile Çin ve 4.336 ton ile ABD izlemiştir (Pamuk Raporu, 2020, s. 3; USDA, 2020a s. 7).

2020-21 dönemi dünya lif pamuk üretimi verilerine bakıldığında ise 25.929 bin ton olan değerin 24.800 bin tona gerilediği görülmektedir. Dünya lif pamuk üretimi sıralamasında bir değişiklik olmasa da, Çin hariç tüm ülkelerde bir önceki döneme kıyasla bir azalma olduğu ya da değerin sabit kaldığı görülmüştür. Tablo 2'de de görüldüğü gibi (bin ton cinsinden) değerler Hindistan'da 6.423, Çin'de 5.987, ABD'de 3.473, Brezilya'da 2.613 ve Pakistan'da 980 olmuştur (USDA, 2020a, s. 7). Daha önce de belirtildiği gibi toplamda bu düşüşün temel nedeninin Covid-19 salgını olduğu düşünülmekte ve bunun sonucunda çiftçilerin dünya genelinde farklı mahsullere yöneldikleri görülmektedir (Organic Cotton Market Report, 2020, s. 3).

Tablo 2. Dünya Lif Pamuk Üretimi (Bin Ton)

\begin{tabular}{ccccccc}
\hline Sira & Ülke & 2016/2017 & 2017/2018 & 2018/2019 & 2019/2020 & 2020/2021 \\
\hline $\mathbf{1}$ & Hindistan & 5.865 & 6.350 & 5.350 & 6.423 & 6.423 \\
$\mathbf{2}$ & Çin & 4.900 & 5.890 & 6.040 & 5.933 & 5.987 \\
$\mathbf{3}$ & ABD & 3.738 & 4.560 & 4.000 & 4.336 & 3.473 \\
$\mathbf{4}$ & Brezilya & 1.530 & 2.010 & 2.730 & 2.928 & 2.613 \\
$\mathbf{5}$ & Pakistan & 1.663 & 1.800 & 1.670 & 1.350 & 980 \\
$\mathbf{6}$ & Özbekistan & 789 & 800 & 640 & 762 & 762 \\
$\mathbf{7}$ & Türkiye & 703 & 792 & 977 & 751 & 610 \\
$\mathbf{8}$ & Meksika & 164 & 335 & 414 & 369 & - \\
$\mathbf{9}$ & Arjantin & 180 & 226 & 257 & 358 & - \\
$\mathbf{1 0}$ & Türkmenistan & 296 & 304 & 300 & 307 & - \\
& Diğer & 3.247 & 3.609 & 3.308 & 3.160 & 3.952 \\
\hline
\end{tabular}

Kaynaklar: Pamuk Raporu, 2020, s. 3; USDA, 2020a, s. 7.

\section{Dünya Lif Pamuk Tüketimi}

Dünya genelinde pamuk üretim değerlerinin en yüksek olduğu ülkelerin aynı zamanda en yüksek pamuk tüketim değerlerine sahip ülkeler olduğu görülmektedir. Son 5 dönemde dünyadaki toplam pamuk tüketiminin 24.000-26.000 bin ton aralı̆̆ında olduğu görülürken, 2019-20 sezonunda bu miktar biraz gerileyerek 22.000 bin ton civarında olmuştur (USDA, 2020a, s. 7). 
TOKEL

Dünya Pamuk Tarımı ve Ekonomiye Katkısı

Tablo 3. Dünya Lif Pamuk. Tüketimi (Bin Ton)

\begin{tabular}{ccccccc}
\hline Sira & Ülke & 2016/2017 & 2017/2018 & 2018/2019 & 2019/2020 & 2020/2021 \\
\hline $\mathbf{1}$ & Çin & 8.000 & 8.500 & 8.250 & 7.185 & 8.274 \\
$\mathbf{2}$ & Hindistan & 5.148 & 5.423 & 5.400 & 4.355 & 5.225 \\
$\mathbf{3}$ & Pakistan & 2.147 & 2.346 & 2.350 & 2.003 & 2.177 \\
$\mathbf{4}$ & Türkiye & 1.455 & 1.481 & 1.555 & 1.437 & 1.524 \\
$\mathbf{5}$ & Bangladeş & 1.455 & 1.660 & 1.579 & 1.415 & 1.589 \\
$\mathbf{6}$ & Vietnam & 1.168 & 1.506 & 1.506 & 1.328 & 1.481 \\
$\mathbf{7}$ & Brezilya & 690 & 680 & 730 & 730 & - \\
$\mathbf{8}$ & Endonezya & 700 & 778 & 700 & 707 & - \\
$\mathbf{9}$ & ABD & 708 & 770 & 644 & 670 & - \\
$\mathbf{1 0}$ & Özbekistan & 371 & 464 & 630 & 653 & 686 \\
& Diğer & 2.655 & 2.732 & 2.674 & 1.736 & 4.219 \\
\hline
\end{tabular}

Kaynaklar: Pamuk Raporu, 2020, s. 4; USDA, 2020a, s. 7.

Çin, yaklaşı \% 30’luk bir değerle dünyadaki en büyük pamuk tüketim oranına sahip ülkedir. Çin’i sirasıyla Hindistan ve Pakistan takip etmektedir. 2020-21 döneminde dünya pamuk tüketimi toplamda bir önceki ylla göre artarak 22.219 bin tondan 25.175 bin tona ulaşırken en çok pamuk tüketen ülkeler sıralamasında ilk üçte bir önceki ylla göre bir değişme olmamıştır. Türkiye, piyasalarda yaşanan durgunluk ve dolardaki artış nedeniyle dördüncülüğü Bangladeş'e bırakarak beşinci sırada yer almıştır (Pamuk Raporu, 2020, s. 4; USDA, 2020a, s. 7).

2019-2020 ve 2020-21 dönemlerine ait verilere bakıldığında ilk beş ülkenin tüketim miktarlarının (bin ton olarak) sırası ile Çin için 7.185 ve 8.274 . Hindistan için 4.355 ve 5.225, Pakistan için 2.003 ve 2.177. Bangladeş için ve Türkiye için 1.437 ve 1.524 olduğu görülmüştür.

\section{Dünya Lif Pamuk Verimleri}

Dünya lif pamuk veriminin en yüksek olduğu ülke uzun yıllar Avustralya olmuştur (Tablo 4). USDA verilerine göre Türkiye son ylllarda lif pamuk veriminde önemli bir artış elde etse de 2019-20 sezonunda verimde yaklaşık \% 20’lik bir düşüş yaşamış ve 5. sıraya gerilemiştir (Pamuk Raporu, 2019 s. 3; USDA, 2020a, s. 9). Bununla birlikte Türkiye, verim açısından dünya ortalamasının oldukça üzerindedir. Dünyanın en büyük pamuk üreticilerinden Hindistan ve pamuk ekim alanlarını genişleten Afrika ülkeleri, dünya ortalamasının altında verimle pamuk üretimi yapmaktadır (Pamuk Raporu, 2020, s. 2).

Tablo 4. Dünya Lif Pamuk Verimleri $(\mathrm{Kg} / \mathrm{Ha})$

\begin{tabular}{ccccccc}
\hline Sira & Ülke & 2016/2017 & 2017/2018 & 2018/2019 & 2019/2020 & 2020/2021 \\
\hline $\mathbf{1}$ & Avustralya & 1.598 & 2.088 & 2.071 & 2.268 & 1.900 \\
$\mathbf{2}$ & Çin & 1.581 & 1.758 & 1.764 & 1.720 & 1.842 \\
$\mathbf{3}$ & Brezilya & 1.629 & 1.707 & 1.640 & 1.759 & 1.686 \\
$\mathbf{4}$ & Meksika & 1.575 & 1.580 & 1.587 & 1.519 & 1.429 \\
$\mathbf{5}$ & Türkiye & 1.674 & 1.714 & 1.944 & 1.318 & 1.742 \\
$\mathbf{6}$ & Yunanistan & 1.009 & 906 & 1.132 & 1.280 & 1.047 \\
$\mathbf{7}$ & ABD & 972 & 1.014 & 964 & 922 & 953 \\
$\mathbf{8}$ & Arjantin & 727 & 688 & 773 & 684 & 665 \\
$\mathbf{9}$ & Sudan & 561 & 444 & 578 & 722 & - \\
$\mathbf{1 0}$ & Özbekistan & 631 & 662 & 712 & 754 & 782 \\
\hline
\end{tabular}

Kaynaklar: Pamuk Raporu, 2020, s. 2; USDA, 2020a, s. 9.

2019-2020 sezonuna ait dünya lif pamuk verimi $(\mathrm{Kg} / \mathrm{Ha})$ değerlerine bakıldığında ilk beş ülkenin sırası ile 2.268 ile Avustralya, 1.759 ile Brezilya, 1.720 ile Çin, 1.519 ile Meksika ve 1.318 ile Türkiye olduğu, bu sıralamanın 2020-2021 sezonunda ise 1.900 ile Avustralya, 1.842 ile Çin, 1.742 ile Türkiye, 1.686 ile Brezilya ve 1.429 ile Meksika şeklinde değiştiği görülmektedir. Bu durum bize, Türkiye'de pamuk ekim alanlarının azalmasına rağmen, uygulanan doğru tarım politikaları ve önlemlerle verimde istikrarın sürdüğünü göstermektedir (Abay, Gümüş ve Türkekul, 2019, s. 24-30; Şaşmaz ve Özel, 2019, s. 53). 


\section{Dünya Genelinde Pamuk Ticareti}

\section{Pamuk İthalatı}

Dünya genelinde başlıca pamuk ithalatçısı ülkeler uzun yıllar boyunca Çin, Bangladeş, Vietnam, Türkiye ve Pakistan olmuştur. Tablo 5’te de görüldüğü gibi, 2019-20 sezonunda dünya pamuk ithalat1 8.728 bin ton olurken bu rakam 2020-21 sezonunda artarak 9.398 bin tona ulaşmış ve dünya ithalatındaki en büyük pay yine Çin'e ait olmuştur (Pamuk Raporu, 2020, s. 8; USDA, 2020a). 2019-20 sezonunda ithalat verilerine bakıldığında sırası ile Çin 1.554, Bangladeş 1.524, Vietnam 1.411, Türkiye 997 ve Pakistan 865 bin ton pamuk ithalatı yaparak ilk beşi oluşturmuş ve genel olarak dünya pamuk ithalatının yaklaşık \% 70’i bu 5 ülke tarafindan gerçekleştirilmiştir. 2020-21 sezonunda ise Pakistan ile Türkiye yer değiştirmiş ve sıralama (bin ton olarak) Çin 2.177, Bangladeş 1.502, Vietnam 1.481, Pakistan 1.023 ve Türkiye 958 şeklinde olmuştur. Yani bir önceki döneme kıyasla Çin, Vietnam ve Pakistan'ın ithalat değerleri artarken Bangladeş ve Türkiye'nin ithalat değerleri azalmıstır (USDA, 2020a, s. 17).

Tablo 5. Dünya Lif Pamuk Ithalatı (Bin Ton)

\begin{tabular}{ccccccc}
\hline Sira & Ülke & 2016/2017 & 2017/2018 & 2018/19 & 2019/2020 & 2020/2021 \\
\hline $\mathbf{1}$ & Çin & 1.096 & 1.320 & 2.100 & 1.554 & 2.177 \\
$\mathbf{2}$ & Bangladeş & 1.412 & 1.670 & 1.540 & 1.524 & 1.502 \\
$\mathbf{3}$ & Vietnam & 1.198 & 1.520 & 1.510 & 1.411 & 1.481 \\
$\mathbf{4}$ & Pakistan & 538 & 671 & 668 & 865 & 1.023 \\
$\mathbf{5}$ & Türkiye & 801 & 880 & 760 & 997 & 958 \\
& Diğer & 3.044 & 2.919 & 2.612 & 2.377 & 2.257 \\
\hline & Toplam & $\mathbf{8 . 0 8 9}$ & $\mathbf{8 . 9 8 0}$ & $\mathbf{9 . 1 9 0}$ & $\mathbf{8 . 7 2 8}$ & $\mathbf{9 . 3 9 8}$ \\
\hline
\end{tabular}

Kaynaklar: Pamuk Raporu, 2020, s. 8; USDA, 2020a, s. 17.

\section{Pamuk İhracatı}

2019-20 sezonunda dünya pamuk lifi ihracatı 8.902 bin ton civarında olmuş ve ABD 3.381 bin ton ve yaklaşık 35'lik bir oranla dünya ihracatında ilk sırada yer almıştır (Tablo 6). Bu dönemde ABD'nin ardından dünyada en çok pamuk ihraç eden 4 ülke sırası ile (bin ton olarak) 1.946 ile Brezilya, 697 ile Hindistan, 319 ile Yunanistan ve 295 ile Mali olmuştur ve dünya pamuk ihracatının yaklaşık \% 70’i bu beş ülke tarafindan gerçekleştirilmiştir (Pamuk Raporu, 2020, s. 9). 2020-21 sezonuna ait verilere göre dünyada toplam ihracatın 9.407 bin ton olduğu ve toplam ihracatta ilk dört ülkenin ABD (3.266 bin ton), Brezilya (2.177 bin ton), Hindistan (1.089 bin ton) ve Yunanistan (283 bin ton) olduğu görülmektedir. Mali’ye ait Aralık ayı değerleri henüz sisteme düşmediğinden burada verilememektedir (USDA, 2020a, s. 17).

Tablo 6. Dünya Lif Pamuk İbracatı (Bin Ton)

\begin{tabular}{ccccccc}
\hline Sira & Ülkeler & 2016/2017 & 2017/2018 & 2018/19 & 2019/20 & 2020/2021 \\
\hline $\mathbf{1}$ & ABD & 3.248 & 3.450 & 3.210 & 3.381 & 3.266 \\
$\mathbf{2}$ & Brezilya & 607 & 910 & 1.450 & 1.946 & 2.177 \\
$\mathbf{3}$ & Hindistan & 991 & 1.130 & 800 & 697 & 1.089 \\
$\mathbf{4}$ & Yunanistan & 221 & 234 & 298 & 319 & 283 \\
$\mathbf{5}$ & Mali & 260 & 289 & 300 & 295 & - \\
& Diğer & 2.862 & 3.082 & 3.172 & 2.264 & 2.592 \\
\hline & Toplam & $\mathbf{8 . 1 8 9}$ & $\mathbf{9 . 0 9 5}$ & $\mathbf{9 . 2 3 0}$ & $\mathbf{8 . 9 0 2}$ & $\mathbf{9 . 4 0 7}$ \\
\hline
\end{tabular}

Kaynaklar: Pamuk Raporu, 2020, s. 9; USDA, 2020a, s. 17.

Dünya pamuk ihracat durumuna bakıldığında, gelişmekte olan ülkelerin küresel ihracat pazarından pay alabilmeleri için $\mathrm{ABD}$ ve Avustralya gibi gelişmiş ülkeler ile rekabet etme zorunluluğunda oldukları görülmektedir. Ayrıca, gelişmekte olan ülkeler kendi aralarında da homojen bir grup oluşturamamaktadır. Çin, Hindistan, Brezilya ve Türkiye gibi ülkeler pamuk üretimi yapan Afrika ülkelerinden ve bazı üretici Asya ülkelerinden ekonomik anlamda daha gelişmiş ülkeler olduklarından küresel pamuk pazarında daha etkin bir rol oynamaktadırlar. Bu durumda zayıf ülkeler ve ekonomiler, dünya pamuk üretiminin ancak \% 5'ini, ihracatının \% 11'ini, ithalatın \% 10'unu ve pamuk kullanımının sadece \% 5 'ini karşılayabilmektedirler (ICTSD, 2013, s. 6; Küçük, 2015, s. 83-103). 


\section{Dünya Pamuk Fiyatları}

Pamuk dış piyasa fiyatlarının şekillenmesindeki en önemli faktörler, Çin ve ABD gibi dünya genelinde pamuk üretimini kontrol altında tutan ülkelerin üretim hacimleri ve stok büyüklükleridir. Pamuk fiyatlarının şekillenmesinde pamuğun yanı sıra yün, tiftik, sentetik iplik gibi dokuma endüstrisi için önemli olan ürünler ve doların diğer ülke para birimleri karşısındaki değeri de dâhil olmak üzere diğer lif ürünlerin üretim hacimleri ve fiyatları da önemli rol oynamaktadır (Koondhar, Qiu, Liu, Abbassi, Koondhar ve Ge 2018, s. 859; Liu ve Hudson, 2019, s. 18-19).

2016-17 ve 2017-18 dönemlerinde Çin'in elinde bulundurduğu pamuk stoklarındaki azalmalar nedeniyle dünya pamuk fiyatları yüksek kalmış, aynı zamanda dünyadaki pamuk tüketim oranları pamuk üretim oranlarının üzerine çıkmıştır. 2018-19 sezonunda pamuk fiyatları yıl ortasında kg başına 2,12 dolara yükselirken, yll sonunda kg başına 1,90 dolara gerilemiştir (Darekar ve Reddy, 2017 s. 374; Ertugrul, Darici, Kiral ve Ayhan, 2018 s. 168; Pamuk Raporu, 2020, s. 14).

Pamukta, diğer tarım ürünlerinde olduğu gibi fiyatları belirleyen önemli unsurlardan biri de zirai ürünlere uygulanan sübvansiyonlardır. Zirai sübvansiyon, zirai işletmelerin, kuruluşların ve çiftliklerin gelirlerini desteklemek, zirai malların arzını yönetmek ve bu malların maliyetini ve arzlarını etkilemek için ödenen bir hükümet teşvikidir (Karnik ve Lalvani, 1996, s. 818). OECD’nin 2020 yllı "Tarım Politikas1 İzleme ve Değerlendirme" raporuna göre, rapor kapsamındaki 54 ülkenin (tüm OECD ve AB ülkelerine ilaveten gelişmekte olan 12 önemli ülke ekonomisi) 2020 yll itibarı ile dünya genelinde ziraat sektörlerine sağladıkları sübvansiyonlar 700 milyar doları bulmuş ve bu miktarın 536 milyar dolarlık büyük çoğunluğu üreticilere yapılan ödemeler şeklinde, geri kalanı ise tüketici desteği ve altyapı yatırımı veya araştırma ve geliştirme gibi hizmetlerin sağlanması şeklinde olmuştur (OECD Raporu, 2020). Her ne kadar zirai sübvansiyonların ülke içi üreticileri destekleyici nitelikleri olsa da uluslararası ticareti bozucu etkileri de bulunabilmektedir. $\mathrm{Bu}$ olumsuz etkiler günümüze kadar birçok uluslararası anlaşmazlığın temelini oluşturmaktadır ve gelecekte de oluşturacağı düşünülmektedir. Yakın geçmişte yaşanan Kanada süt sübvansiyonları $\mathrm{ABD}$ için belki de ziraat ile ilgili en büyük sorunlardan biri olmuştur. Neredeyse tüm dünya ülkeleri, Brezilya, Hindistan Avustralya ve Guatemala'nın şeker endüstrisine yaptığı sübvansiyonlara itiraz etmiştir. Gelişmiş ülkeler ile aynı destekleri sağlayamayan az gelişmiş ülkelerin hükümetlerinin bu konudaki en büyük şikâyetleri, küçük üreticilerin bu durumdan orantısız bir şekilde etkilenerek daha zengin ülkelerin yüksek sübvansiyonlu üreticileri ile rekabet edemez hale gelmeleridir (Globaltrademag, 2020). Yine OECD raporu bize göstermektedir ki, dünya genelinde Norveç, İzlanda ve İsviçre gibi daha küçük ülkeler, brüt çiftlik gelirlerinin sırasıyla $\% 57,6, \% 54,6$ ve \% 47,4'lerini destek olarak verip başı çekerken toplam harcama açısından Çin, $\mathrm{AB}$ ve ABD ilk üçü sırayı oluşturmaktadır. Bununla birlikte, Çin, sonraki en büyük harcamaları yapan $A B, A B D$ ve Japonya'nın toplamından daha fazlasını harcamaktadır. Ülkeler itibarı ile uygulanan tarımsal sübvansiyon miktarlarına bakıldığında; Çin 185,9 milyon $\$$, AB 101,3 milyar \$, ABD 48,9 milyar \$, Japonya 37,6 milyar \$, Endonezya 29,4 milyar \$, Kore 20,8 milyar \$, Rusya 7,9 milyar \$, Filipinler 7,3 milyar \$, Türkiye 6,7 milyar \$ ve İsviçre 6,2 milyar \$ olduğu görülmektedir (OECD Raporu, 2020).

Pamuk piyasalarındaki Çin ve ABD egemenliği, özellikle düşük gelirli üreticilere sahip ülkelerin geçim kaynaklarını olumsuz yönde etkilemektedir (Voora, Larrea ve Bermudez, 2020, s. 4). Pamuk üretiminin önemsenmeyecek bir seviyede olduğu $\mathrm{AB}$ ülkeleri bile çiftçilerine birim üretim başına en yüksek sübvansiyonları sağlamaktadır (Küçük, 2015, s. 101). ABD, Çin ve Rusya gibi gelişmiş ülkelerde pamuk üreticilerine sağlanan yüksek sübvansiyonlar ve düşük fiyatlar, geçimini büyük ölçüde pamuktan kazanan Benin, Burkina Faso, Çad, Mali ve Togo gibi az gelişmiş Afrika ülkelerinde çiftçilerin ürünlerini uygun olmayan düşük fiyatlara satmak zorunda birakarak rekabet gücünü azaltmaktadır (Laouan, 2021, s. 47; Voora, vd., 2020, s. 5). Hindistan, Türkiye, Yunanistan, İspanya ve Kolombiya da pamuk sektörüne sübvansiyonlar sağlayan ülkelerdendir (Küçük, 2015, s. 106).

Hâlihazırda, dünya pamuk ticaretindeki olaylara, risklere, tehditlere (özellikle Çin ile ABD arasındaki ticaret savaşlarına) ve stok politikalarına bağlı olarak dünya pamuk üretimi ve tüketimi pamuk fiyatları üzerinde etkili olmaya devam etmektedir (Boylan, McBeath ve Wang, 2020 s. 2-3). He ne kadar 2019 yllında dünya pamuk fiyatları zaman zaman kg başına 1,92 dolara çıkarılmasına rağmen, genel olarak önceki yıllara göre daha düşük bir eğilim izlemiştir. 2020-21 döneminde, özellikle Covid-19 salgınının etkisi ile yaşanan kargaşanın pamuk piyasalarındaki olumsuz etkilerini durdurmak için büyük üretici ve tüketici ülkeler dünya pamuk fiyatlarını düşürme eğilimine girmişlerdir. Ancak sonrasında ABD'deki olumsuz hava koşulları yüzünden üretimin düşmesi, ardından Çin, Bangladeş, Vietnam ve Pakistan'dan gelen yüksek 
pamuk talebi nedeniyle fiyatlar yükselmiştir. Dünya pamuk fiyatları Nisan ayı ortalama $1,40 \$ / \mathrm{kg}$ iken Ekim ayında ortalama 1,65 \$/kg olmuştur. Salgının son dalgasının yaşandığı Aralık 2020 döneminde ve 2021 başlarında ülkelerin yeniden kısıtlamalar getirmesi durumunda giyim eşyalarına tüketiciler tarafından gerçekleşecek olası bir talep düşmesinin pamuk fiyatlarını baskılayabileceği düşünülmektedir. Diğer taraftan, 2021 itibarı ile Covid-19'un etkisinin hafif olması durumunda ise pamuğa olan talebin artacağı ve bunun pamuk fiyatlarına olumlu yönde yansıyacağı düşünülmektedir (Tarım Orman, 2020a, s. 12).

\section{Organik Pamuk Tarımı}

Türkiye Cumhuriyeti, Tarım, Orman ve Köy İşleri Bakanlı̆̆ı, organik tarım tanımını "İnsan sağlı̆̆ına ve çevreye zarar vermeyen ve üretimde kimyasal girdi kullanılmadan, üretimden tüketime kadar her aşaması kontrollü ve sertifikalı tarımsal üretim biçimidir. Doğal dengeyi koruyarak hava ve su gibi yaşamsal kaynakların ve doğal hayatın korunmasını amaçlayan bir üretim yöntemidir” şeklinde yapmaktadır (Tarım Orman, 2020b). Tanımından da anlaşılacağı üzere, organik tarım uygulamaları, bir üretim yönetimi sistemi olarak topraktaki biyolojik faaliyetlere teşvik sağlamakta ve biyolojik çeşitliliğe sürdürülebilirlik kazandırmaktadır. Ayrıca doğada organik tarım uygulamalarının ve geliştirilmesi yoluyla organik bazlı üretimin sonucu olarak ekolojik bir uyum ortaya çıkmaktadır (Gunaydin, Yavas, Avinc, Soydan, Palamutcu, Simsek, Demirtas, Ozkan ve Kivilcim, 2019, s. 116). Toprak verimliliğine önem verilen ve çeşitli biyolojik tarım uygulamalarının kullanıldığı organik tarım sistemleri günümüzde tercih edilebilir sistemler olarak kabul edilmektedir. Bununla bağlantılı olarak, biyolojik çeşitlilik ve biyolojik döngülerin organik tarımın uygulanmasıyla iyileştirileceği düşünülmektedir (Eyupoglu, 2019, s. 159).

ABD, Çin ve Türkiye gibi bazı ülkeler, organik pamuk olarak bilinen, gübre ve pestisitlerin kullanılmadığı, çevre dostu yöntem ve malzemelerin uygulamalarıla doğal pamuk (aynı zamanda transgenik olmayan) üretmektedir (Gunaydin vd., 2019, s. 116; Organic Cotton Market Report 2020, s. 3). $\mathrm{Bu}$ ülkeler içinde özellikle Türkiye'de resmi düzenlemeler nedeniyle genetiği değiştirilmiş organizma (GDO)'lara ait tohumların organik tarım için kullanılması yasaklanmıştır (Eyupoglu, 2019, s. 159; Tarım Orman, 2020b). Organik pamuğun tercih edilme sebepleri ve avantajlarına aşağıdaki şekilde sıralanabilir;

1. Kimyasal kullanımını içermeyen üretim süreçleri,

2. Geleneksel pamuğa göre daha kaliteli oluşu,

3. Sağlık ve çevre dostu uygulamalar ile üretilmiş olması (Herbisit ya da insektisit kullanılmamış toprak ve su kirliliğini önlemeye tarımsal uygulamalar),

4. Biyolojik çeşitliliğin korunmasına yönelik uygulamaları içermesi,

5. Çiftçiler ve aileleri için daha iyi sağlık koşullarının sağlandığı uygulamalar ile üretilmeleri,

6. Elde edilen pamuk lifinin insan deri ve dokularına uyumlu olmas1,

7. Sonuç olarak ticari anlamda tercih edilebilir bir pamuk olması.

Yukarıda belirtilen sebeplerden dolayı, dünya genelinde organik pamuğa gereksinim artmakta ve organik pamuk kullanımı yaygınlaşmaktadır. Ülkeler bazında bakıldığında, Türkiye dünyada ilk organik pamuk üreten ülkedir ve günümüzde de organik pamuk üreten başlıca ülkelerin başında gelmektedir.

Organik pamuktan üretilen tekstil ürünleri, insana olduğu kadar çevreye de zarar vermeyen hassas süreçler kullanılarak üretildiklerinden organik pamuk, geleneksel üretime göre çevreye, ekonomiye ve sosyal kalkınmaya olumlu katkılar sağlayan bir üründür (Aytac, Basbag, Arslanoglu, Ekinci ve Ayan, 2020 s. 475). Organik pamuğun kullanım alanları, giyim, ayakkabı, ev tekstili (havlu, bornoz, çarşaf, nevresim vb.), çocuk eşyaları (çamaşır, giysi, oyuncak, çocuk bezi vb.) ve kişisel bakım ürünleri (makyaj pamuğu, pamuklu çubuklar vb.) gibi geniş bir yelpazeyi kapsamaktadır (Aksoy, Duman, Besirli ve Kenanoglu Bektas, 2020, s. 198).

Bugün, küresel organik pamuğun büyük bir kısmı (\% 97) aşağıdaki ülkeler tarafindan üretilmektedir: Hindistan (\% 51), Çin (\% 17), Türkiye (\% 10), Kirgızistan ( $\%$ 10), Tacikistan (\% 5), Tanzanya (2\%) ve ABD (\% 2). Geriye kalan $\% 3$ ise Uganda ( $\% 1,08)$, Yunanistan ( $\% 0,49)$, Benin $(\% 0,42)$, Peru ( $\% 0,23)$, Burkina Faso (\% 0,19), Pakistan (\% 0,17), Misir (\% 0,12) Etiyopya (\% 0,05), Brezilya (\% 0,04), Mali (\% $0,03)$, Arjantin $(\% 0,005)$ ve Tayland $(\% 0,003)$ olmak üzere 12 farklı ülkede üretilmektedir. Organik pamuk, 2018-2019 yillarında toplam 19 ülke tarafindan üretilmiştir (Organic Cotton Market Report, 2020 s. 4).

Klasik yöntemle üretilen pamuk verimine kıyasla organik pamuk üretiminde verimin \% 7-38 arası daha düşük olması organik pamuk üretiminde önemli bir problem olarak karşımıza çıkmaktadır. Organik 
pamuk üreten çiftçilerin karşılaştı̆ı bu verim kayıpları, organik pamuk üretiminin teşvik edilebilmesi için üreticilerin zarar görmeyeceği şekilde farklı ve yüksek fiyat oranları uygulanarak telafi edilmelidir (Aksoy vd., 2020, s. 192; Aytac vd., 2020, s. 476). Organik pamuk üretimindeki diğer bir sorun ise genetiği değiştirilmiş (GM) pamuktan kaynaklanan kontaminasyon riskidir. Türkiye dışındaki diğer ülkelerde pamuk dâhil genetiği değiştirilmiş bitkilerin ekiliyor olması kontaminasyon olasılığını artırmaktadır. Türkiye'de genetiği değiştirilmiş bitki tarımının kanunlarla yasaklanmış olması, GM pamuğun organik pamuğu kontamine etmesi riskini ortadan kaldırmaktadır (Basal, Karademir, Goren, Sezener, Dogan, Gencsoylu ve Erdogan, 2019, s. 302). Ayrıca organik üretimde hasadın tarladan son ürün aşamasına kadar her aşamada sertifikasyon sürecinden geçmesi gerekmektedir. Organik pamuk üretiminde üreticiden tüketiciye uzanan uzun zincire ek olarak, kontrol ve sertifikasyon da süreci etkilemektedir (Çetin, 2018, s. 130; Kalkanc1, 2017, s. 17-18).

Her ne kadar organik pamuk tarımı üretim için geleneksel pamuk yetiştiriciliğine göre düşük verim ve yüksek maliyet getirmesi nedeniyle çiftçiler tarafından çok popüler görülmese de, ülke ihracatı için önemlidir ve aynı zamanda çiftçilere yüksek gelir sağlamaktadır. Ekolojik açıdan olumlu etkilerin de hesaba katıldığında, uygun tarım politikaları ile desteklenmesi gerekmektedir (Küçük ve Iss1, 2019, s. 396; Manc1 ve Binici, 2009, s. 2).

\section{Transgenik-Genetiği Değiştirilmiş Pamuk Tarımı}

1996 yılında üretimine başlanan genetiği değiştirilmiş organizma (GDO)'ların ekim alanları günümüze kadar 1,7 milyon hektardan 200 milyon hektara kadar ulaşmıştır (Arvas ve Kocaçalışkan, 2020, s. 202). Transgenik tarım uygulamaları için kullanılan arazinin neredeyse tamamı (\% 99), dünyada üretilen dört transgenik ürün için kullanılmaktadır. Bunlar GM soya fasulyesi (\% 50), GM mısır (\% 31), GM pamuk (\% 13) ve GM kanoladır (\% 5). Transgenik tarımın yapıldığ ilk 4 ülke ise ABD (\% 40), Brezilya (\% 26), Arjantin (\% 12) ve Kanada (\% 7)'dir (Paull ve Hennig, 2019, s. 1-2; Wu, Zhang, Wu, Qian, Zhang, Wang ve Wu, 2020, s. 1).

Yukarıda da belirtildiği gibi, dünya üzerinde yetiştirilen ilk dört genetiği değiştirilmiş üründen biri pamuktur ve son yıllarda, dünya çapında birim alandan yüksek miktarlarda kaliteli ürün elde etmek için, GM pamuk ekim alanlarında büyük bir artış olmuştur. GM pamukta, herbisit toleransı ve/veya zararlı böceklere karşı direnç özellikleri istenen özelliklerdir. Bacillus thurengiensis (Bt) bakterisinden izole edilerek pamuğa aktarılan bir gen sonucu üretilen proteinler pamuk yapraklarını yiyen zararlı böceklerin ölmelerine sebep verir ve bu özellikleri taşıyan pamuklar Bt pamuk olarak adlandırllırlar (Jin, Wang, Guan, Zhang, Yu, Liu, Liu, Xue, Li, Wu, Wang, Yang, Abdelgaffar, Jurat-Fuentes, Tabashnik ve Wu, 2018, s. 11760; Lapegna ve Perelmuter, 2020, s. 2; Tokel, Genc ve Ozyigit, 2021, s. 5). Transgenik pamuk veya biyoteknolojik pamuk olarak da adlandırılan Bt pamuk, ilk olarak 1993 yllında ABD'de saha denemeleri için onaylanmış ve 1995 yılında ticari kullanımına başlanmıştır. Bt pamuk 1997 yılında Çin tarafından, 2002 ve sonraki ylllarda ise Hindistan ve Meksika, Arjantin, Avustralya ve Güney Afrika, Brezilya, Burkina Faso ve Kolombiya dâhil olmak üzere diğer ülkeler tarafından onaylanarak ve tarımına başlanılmıştır (Baffes, 2004, s. 7; Gruere, 2012, s. 6-7; Kranthi ve Stone, 2020, s. 189; Qiu, 2010, s. 1-2).

Acquisition of Agri-biotech Applications (ISAAA)'ya göre, 2018 yllında dünya çapında 15 ülke Btpamuk tarımı yapmıştır (ISAAA, 2019, s. 1). 2017 yllında Bt-pamuk ekili alanlar 24,1 milyon hektar iken, bu say1 2018 yllinda 24,9 milyon hektara yükselmiştir (Shera, Karmakar, Sharma ve Sangha, 2018, s. 1). Ayrıca bu arazilerin 18,14 milyon hektarına böceklere dayanıkl, 757.000 hektarına herbisite dayanıklı ve 5,97 milyon hektarına da hem böceklere, hem de herbisite dayanıklı pamuklar dikilmiştir. 2018 yılında Hindistan en fazla Bt pamuk ekiminin yapıldığ ülke olurken ABD, Çin, Pakistan ve Brezilya ilk sıralarda yer almıştır. Mega Bt-pamuk üreten ülkeleri Arjantin, Myanmar, Avustralya, Sudan, Meksika, Güney Afrika, Paraguay ve Kolombiya izlemektedir (ISAAA, 2019, s. 1).

Bt-pamuk ağırlıklı olarak liflerinden ve yağından insanların yararlandığı, küspesinin de hayvan yemi olarak kullanıldığı bir üründür. Hindistan, $\mathrm{ABD}$ ve Brezilya'dan sonra üçüncü büyük $\mathrm{Bt}$ pamuk ihracatçısıdır (USDA, 2020b, s. 6).

\section{Covid 19'un Pamuk Tarımı ve Ekonomisine Etkileri}

Aralık 2019'un başlarında dünya, Çin'in Hubei eyaletine bağlı Wuhan şehrinde ortaya çıkan SARSCoV-2 ile tanıştı ve günümüze kadar SARS-CoV-2 dünya çapında 220 ülkeye yayıldı (Genc, 2020, s. 72; Uras, 2021, s. 1). Dünya Sağlık Örgütü’ne göre Aralık ayı itibarı ile dünya çapında 65.651.683 doğrulanmış vaka ve 1.519.193 ölüm varken ABD 14.191.298 toplam vaka ile salgının merkez üssü haline gelmiştir. 
ABD'yi Hindistan, Brezilya ve Rusya izlemiştir (WHO, 2020). Covid-19, dünyanın dört bir yanındaki kırsal ve kentsel alanların ticaret ve ulaşım için etkin bir şekilde kapatılmak zorunda bırakıldığı bir salgın olmuştur. Sınırların kapatılması, karantinalar ve değer zinciri aksaklıkları gıdaya erişimi kısıtlarken, girdi eksiklikleri ve bunları satın almanın finansal araçları üretim yeteneklerini tehlikeye atmıștır (Shirsath, Jat, McDonald, Srivastava, Craufurd, Rana ve Jat, 2020, s. 2). Bunun sonucunda, ekonomiye ve istihdam yaratmaya büyük katkı sağlayan turizm, konaklama, havacıllk, tekstil, tarım, inşaat, değerli taş/mücevher ve start-up gibi sektörler salgın sırasında büyük kayıplara uğramıştır (Seetharaman, 2020, s. 1).

Ekonominin her alanında olduğu gibi tarım sektörü de Covid-19'dan olumsuz etkilendi. Salgın sırasında buğday, sebze ve diğer mahsullere olan talep arttı. Ancak tarımsal çıktılar, tedarik zinciri sorunları nedeniyle tüketicilere yeterli ölçüde ulaşamadı ve sonuç olarak çiftçiler ürün fiyatlarını düşürmek zorunda kaldılar. İlaveten, hasat faaliyetlerini yürütecek göçmen işgücünün bulunmaması ve tedarik zincirlerindeki aksakliklar tarım sektörünü olumsuz etkileyen faktörlerden oldu (Pan, Yang, Zhou ve Kong, 2020, s. 2). Salgın sırasında tekstil fabrikalarının kapanması, çiftlik girdilerinde ve mevsimlik işçilikte yaşanan sıkıntılar, pamuğa olan talebin azalması ve pamuk fiyatlarındaki düşüss, pamuk sektörünü olumsuz etkilemiştir (Clapp ve Moseley, 2020, s. 1402; Lioutas ve Charatsari, 2021, s. 103023). Ayrıca, otellerin, restoranların, kafelerin kapanması da tarımsal ürünlerin satışlarını etkiledi. Covid-19'dan diğer tarım ürünleri gibi pamuk ta olumsuz etkilendi (Debata, Patnaik ve Mishra, 2020 s. 2; Henry, 2020, s. 1095).

Covid-19 krizinden önce, pamuk sektörünün, esas olarak tekstil ve konfeksiyon sektörlerinin taleplerine bağlı olarak istikrarlı bir şekilde büyümesi bekleniyordu ve bu talebin yüksek oranda AsyaPasifik'te yoğunlaşacağı düşünülüyordu (Mordor Intelligence, 2018, s. 1). 2017 yllında bu bölge, küresel hazır giyim üretiminin \% 61'ini ve perakende pazar değerinin \% 37,1'ini oluştururken, onu Avrupa takip etti. Bununla birlikte sektörler, pamuk için nihai talebi etkileyen nüfus ve ekonomik büyümeye karşı çok duyarllydı (Voora vd., 2020, s. 3). Covid-19 krizinden önce ekonomistler, arz ve taleple ilgili çeşitli faktörler nedeniyle pamuk sektörünün 1 lımlı büyümesini öngörüyorlardı. Covid-19, küresel ekonominin neredeyse her sektörünü pamuk sektörü de dâhil olmak üzere çarpıcı bir şekilde etkiledi (USDA, 2020a, s. 1). Ayrıca, mevcut ABD-Çin ticaret savaşı pamuk ekonomisi üzerindeki belirsizliği körükledi. Çünkü ABD konfeksiyon ürünlerini çoğunlukla Çin'den temin etmekteydi ve bu sebepten küresel pamuk talebi aşağ1 yönlü revize edildi (Voora vd., 2020, s. 3).

Salgından önce yükselen fiyatlar Ocak ayından Nisan ayına kadar keskin bir şekilde geriledi ve NY vadeli işlemleri 10 yılın en düşük seviyesine düştü. Ancak, fabrika kullanımının toparlanması ve diğer faktörlerin son güçlenmeyi desteklemesi nedeniyle fiyatlar yükseldi (USDA, 2020a, s. 1). Birçok fabrika ve işletme, batılı giyim markalarının sipariş iptallerine ve mevcut siparişlerin askıya alınmasına neden olan halk sağlığı direktifleri nedeniyle kapandı. Bu durumun ilerleyen süreçte özellikle Bangladeş ve Hindistan gibi ülkelerdeki pamuk ekim alanlarına ve tekstil fabrikalarına zarar vermesi beklenmektedir (Kelly, 2020, s. 1; Alam, 2020 s. 1, Voora, Larrea ve Bermudez, 2020, s. 3). Salgın sirasinda Hindistan'da pamuk tüketimi bir önceki ylla göre artarak 5.225 bin metrik tona ulaştı. Artan talep ve tüketime rağmen kapanış stokları 2020/21 sezonunda hafif bir artışla 3.937 bin metrik tona yükseldi. 2019/20 sezonunda 6.423 bin metrik ton pamuk ithal edilmesine rağmen, özel kuruluşlar tarafindan büyük miktarda pamuk satın alındığı için 2020/21 döneminde sadece 174 bin metrik ton ithalat yapıldı. 2019/20 sezonunda Çin'in pamuk ihracatı 14,1 milyar dolara ve 34 bin metrik tona ulaşmasına rağmen, salgin nedeniyle Ocak 2020/21 sezonunda 27 bin metrik tona düşmesi beklenmektedir (Worldstopexports, 2020; USDA, 2020c, s. 1). Dünyanın en büyük pamuk ihracatçısı olan $\mathrm{ABD}$, salgında işçi sıkıntısı ile karşılaştı. Çünkü uzun yıllardır işgücünün neredeyse yarısını yurtdışından, özellikle de Meksika'dan karşılıyordu (Charlton ve Castillo, 2021, s. 45). ABD'de salgın döneminde artan taleple kapanış stokları yaklaşı $\% 50$ oranında azaldı (USDA, 2021, s. 16). Ülkede pamuk ithalatı neredeyse hiç yapılmazken, 2019/20 sezonunda 7,9 milyar ABD doları tutarında pamuk ihracatı yapıldı (Worldstopexports, 2020). ABD yönetimi salgı̀n döneminde, Çin'de en çok pamuk üretimi yapılan Sincan bölgesinden pamuk ithalatına ilaveten bu bölgede yetiştirilen pamukla yapılan tüm giyim ve tekstil ürünlerinin de ithalatını yasakladı (Reuters, 2021). Ayrıca bu dönemde Çin'in ABD ürünlerine uyguladığ1 tarifeler nedeniyle Çin'e pamuk ihracatı da azaldı (Muhammad ve Jones, 2021, s. 102351). Brezilya'da Covid-19'un pamuk talep ve fiyatları üzerindeki olumsuz etkileri, 2020'nin başından itibaren pamuk fiyatlarında düşüşlere neden olurken, üretim maliyetlerinde (gübre, herbisitler, makine arzı, işçilik vb.) artışlar görüldü. Bu durum, ülkenin en çok pamuk yetiştiren eyaletleri olan Mato Grosso ve Bahia'da pamuk ekim alanlarının \%10-20 oranında azalmasına ve çiftçilerin soya ve mısır bitkilerine yönelmelerine neden oldu (Tarım Orman, 2020c, s. 1-2). Aralık 2020 itibarı ile Pakistan, Hindistan ve Avustralya'daki keskin düşüş gösteren üretim, Türkmenistan'daki artışla kısmen dengelendi. Hindistan, Çin 
ve Pakistan'da tüketim arttı, ancak Tayland'da düştü. Küresel ticaret ise Bangladeş ve Tayland'da az da olsa artma eğilimine girdi. İlerleyen dönemde ABD'de keskin bir şekilde daha düşük üretim ve daha yüksek ihracat olacağ1 tahmin edilmektedir (USDA, 2020a, s. 1).

Yukarıda da görüldüğ̈ gibi, pamuk üretimi ve pamuk ticareti Covid-19'dan olumsuz etkilenmiştir. Özellikte dünya pamuk ticaretinde söz sahibi olan ülkelerde, pamuk ithalatı ve ihracatı bir önceki yıla göre değişmiş, ülkelerin kazançları azalmıştır. Covid-19 salgını boyunca fiyatlardaki hızlı değişimler, çiftçilerin yaşadığ1 zorluklar, işçi hareketinin kıstlanması ve gelecekteki belirsizlikler nedeniyle kırılgan tarım ekonomilerinin durumunun ne olacağı henüz bilinmemektedir. Küresel anlamda, Covid-19 salgınının kontrole alınabileceği zaman ile ilgili kesin bir bilginin olmaması da, salgın sonrası herhangi bir öngörüde bulunmayı da güçleştirmektedir. Yine de küresel ekonominin, 2021 yllında da bir önceki yll olduğu gibi daralacağ1 konusundaki beklentiler giderek yaygınlaşmaktadır. Bu durumda, hükümetler ile birlikte merkez bankalarının azim ve kararlılık göstererek aldıkları önlemlerin reel ekonomiye duyulan güvenin ve piyasa hareketlerinin normalleşmesi için kısa vadede etkili olmayacağı düşünülmektedir (Hazır Giyim, 2020, s. 13).

\section{Tartışma, Sonuç ve Öneriler}

Günümüzde tekstil ve hazır giyim ürünlerinde sentetik liflerin kullanılmasındaki artış pamuğun küresel lif pazarındaki payını \% 35’e kadar düşürse de tekstilde ve tıbbi kullanımda girdi olarak kullanılan başlıca doğal lif pamuktur. Yenilenebilir bir kaynak olan pamuk bu özelliği ve asla yeri doldurulamayışı ile doğal kaynaklar, sermaye ve işgücü gibi ekonomik faktörlerin istihdamını sağlayabilmekte ve ekonomiye büyük bir katkı sağlamaktadır. Dünya genelinde yaklaşık 100 milyon çiftçi ailesi geçimini pamuk tarımından sağladığı ve özellikle son yıllarda pamuk tarımının yaygınlaştı̆̆ı Benin, Burkina Faso, Çad, Mali ve Togo gibi Afrika ülkelerinde yurt içi hasılanın \% 5-10’unu, toplam ihracat gelirlerinin üçte birinden fazlasını ve tarımsal ihracatın üçte ikisinden fazlasını oluşturduğu ve bu ülkelerde dolaylı yoldan ekonominin arkasındaki ana güç olduğu görülmektedir.

Dünya ekonomisinde bu denli büyük öneme sahip olan pamuk sektöründe bazı olumsuzluklar ve çözülmesi gereken sorunlar vardır. Örneğin, küresel iklim değişikliği, sıcaklık ve yağışların bölgesel etkileri, zamanla dünya genelinde ortalama sıcaklikların artması gibi faktörler, pamukta bu tür değişimlere adaptasyon noktasında ciddi sıkıntılar oluşturmaktadır. Karlılığın azalması, gereğinden fazla enerji ve aşırı su kullanımı, su kalitesizliği, çevresel problemler ve transgenik tohumların ekilmesi dâhil olmak üzere dünya çapında pamuk eken çiftçilerin karşılaştı̆̆ birçok farklı tehdit türü vardır. Bunlara ilaveten, en büyük üretici ülkeler olan Çin ve Hindistan arasındaki rekolte eşitsizlikleri de $(1.800 \mathrm{~kg} / \mathrm{ha}$ 'a karşlık $500 \mathrm{~kg} / \mathrm{ha})$ dikkat çekicidir. Ayrıca son bir yıldır tüm dünyayı etkileyen Covid-19 salgınının da pamuk ekonomisine olan olumsuz etkileri bilinmektedir.

Yukarıdaki sorunların çözülmesi ve pamuk lifinin tekstil sektöründe rekabetçi ve sürdürülebilir kalmasını sağlamak amacı ile dünya genelinde bazı düzenlemeler yapılmalıdır. Bu bağlamda, pamuk ekim alanlarını genişletmeyi amaçlayan tarım politikaları geliştirilmeli ve özellikle yüksek verim ve kaliteli üretim yapılabilen bölgelerde uygulanmalıdır. Dünya genelinde yüksek maliyet sorununu çözmek, üretimi artırmak ve rekabetçi bir ortam yaratabilmek için pamuk politikaları yeniden değerlendirilmeli, pamuk fiyatlarının $A B D$ ve Çin gibi birkaç ülke tarafından değil, küresel ölçekte diğer üretici ülkelerin katkıları ile belirlenmesi sağlanmalıdır. Ayrıca, piyasalar genetiği değiştirilmiş pamuğun tekelinden kurtarılmalı ve dünya genelinde pamuğun kalitesinin artırılması için bilimsel çalışmalar desteklenmeli ve yüksek verimli pamuk eldesi için "elit gen havuzları" oluşturulmalıdır.

\section{Etik Beyan}

"Dünya Pamuk Tarımı ve Ekonomiye Katkısı" isimli çalışmanın yazım sürecinde bilimsel, etik ve alıntı kurallarına uyulmuş; toplanan veriler üzerinde herhangi bir tahrifat yapılmamış ve bu çalışma herhangi başka bir akademik yayın ortamına değerlendirme için gönderilmemiştir. Bu araştırma doküman incelemesine dayalı olarak yapıldığından etik kurul kararı zorunluluğu bulunmamaktadır.

\section{Kaynakça}

Abay, C. F., Güler Gümüş, S. ve Türkekul, B. (2019). Türkiye'de 2000 y1lı sonrası uygulanan tarım politikaları. In B. Pakdemirli, B. Yücel \& N. Koşum (Eds.), Türkiye'de geşmişten günümüze tarm politikalar ve ekonomisi (pp. 21-38). Akçağ Yayınları: 1594

Aksoy, U., Duman, I., Besirli, G. ve Kenanoglu Bektas, Z. (2020). Türkiye'de organik bitkisel üretim. Türkiye Ziraat Mühendisligi IX. Teknik. Kongresi Bildiriler Kitabı-1, 191-211. 
Arvas, Y. E. ve Kocaçalışkan, İ. (2020). Genetiği değiştirilmiş bitkilerin biyogüvenlik riskleri. Türk Doğa ve Fen Dergisi, 9(2), 201-210.

Aytac, S., Basbag, S., Arslanoglu, F., Ekinci, R. ve Ayan A. K. (2020). Lif bitkileri üretiminde mevcut durum ve gelecek. Türkiye Ziraat Mühendisliği IX. Teknik Kongresi Bildiriler Kitabı-1, 463-492.

Baffes, J., (2004). "Cotton Market Setting, Trade Policies, and Issues". World Bank Policy Research Working Paper, No: 3218, 88.

Basal, H., Karademir, E., Goren, H. K., Sezener, V., Dogan, M. N., Gencsoylu, I. ve Erdogan, O. (2019). Cotton production in Turkey and Europe. In K. Jabran \& B. S. Chauhan (Eds.), Cotton production (pp. 297-321). Wiley Online Library.

Boylan, B. M., McBeath, J. ve Wang, B. (2020). US-China relations: Nationalism, the trade war, and COVID-19. Fudan Journal of the Humanities and Social Sciences, 1-18.

Charlton, D. ve Castillo, M. (2021). Potential impacts of a pandemic on the US farm labor market. Applied Economic Perspectives and Policy, 43, 39-57.

Chohan, S., Perveen, R., Abid, M., Tahir, M. N. ve Sajid, M. (2020). Cotton diseases and their management. In S. Ahmad \& M. Hasanuzzaman (Eds.), Cotton production and uses (pp. 239-270). Singapore: Springer.

Clapp, J. ve Moseley, W. G. (2020). This food crisis is different: COVID-19 and the fragility of the neoliberal food security order. Journal of Peasant Studies, 47(7), 1393-1417.

Çetin, M. D. (2018). Organik tarm ve pamuk, organic agriculture and cotton. International Academic Research Congress, INES 2018, 130-135.

Dai, J. ve Dong, H. (2014). Intensive cotton farming technologies in China: Achievements, challenges and countermeasures. Field Crops Research, 155, 99-110.

Darekar, A. ve Reddy, A. A. (2017). Cotton price forecasting in major producing states. Economic Affairs, 62(3), 373-378.

Datta, A., Ullah, H., Ferdous, Z., Santiago-Arenas, R. ve Attia, A. (2020). Water management in cotton. In K. Jabran \& B. S. Chauhan (Eds.), Cotton production (pp. 47-60). Wiley Online Library.

Davidonis, G. H. ve Hamilton, R. H. (1983). Plant regeneration from callus tissue of Gossypium birsutum L. Plant Science Letters, 32(1-2), 89-93.

Debata, B., Patnaik, P. ve Mishra, A. (2020). COVID-19 pandemic! It's impact on people, economy, and environment. Journal of Public Affairs, 20(4), e2372.

Ertugrul, H. M., Darici, B., Kiral, H. ve Ayhan, F. (2018). Transmission of world cotton price to domestic cotton price in Turkey. Politico-Economic Evaluation of Current Issues, 165-173.

Eyupoglu, S. (2019). Organic cotton and environmental impacts. In M. Gardetti \& S. Muthu (Eds.), Organic cotton (pp. 157-176). Springer, Singapore.

Gao, W., Long, L., Tian, X., Jin, J., Liu, H., Zhang, H., ... ve\& Song, C. (2016). Genome-wide identification and expression analysis of stress-associated proteins (SAPs) containing A20/AN1 zinc finger in cotton. Molecular Genetics and Genomics, 291(6), 2199-2213.

Genc, B. N. (2020). Critical management of COVID-19 pandemic in Turkey. Frontiers in Life Sciences and Related Technologies, 1(2), 69-73.

Gillson, I., Poulton, C., Balcombe, K. ve Page, S. (2004). Understanding the impact of cotton subsidies on developing countries. Munich Personal RePEc Archive, 1-144.

Gruere, A., (2012). Recent trends in biotech cotton production. International Cotton Advisory Committee (ICAC), Cotton: Review of the World Situation, 65(5), 6-7.

Gunaydin, G. K., Yavas, A., Avinc, O., Soydan, A. S., Palamutcu, S., Simsek, M. K., ... ve Kivilcim, M. N. (2019). Organic cotton and cotton fiber production in Turkey, recent developments. In M. Gardetti \& S. Muthu (Eds.), Organic cotton (pp. 101-125). Springer, Singapore.

Gustafson, D. I., Collins, M., Fry, J., Smith, S., Matlock, M., Zilberman, D., ... ve Ramsey, N. (2014). Climate adaptation imperatives: global sustainability trends and eco-efficiency metrics in four major crops-canola, cotton, maize, and soybeans. International Journal of Agricultural Sustainability, 12(2), 146163.

Gündüz, F. F., Özlem, A., Gündüz, S. ve Dölekoğlu, C. (2020), Determination of the factors affecting cotton export of Turkey: A panel gravity model approach. Akademik Hassasiyetler, 7(13), 547-564.

Hayat, K., Bardak, A., Parlak, D., Ashraf, F., Imran, H. M., Haq, H. A., ... ve Akhtar, M. N. (2020). Biotechnology for cotton improvement. In S. Ahmad \& M. Hasanuzzaman (Eds.), Cotton production and uses (pp. 509-525). Singapore: Springer. 
Henry, R. (2020). Innovations in agriculture and food supply in response to the COVID-19 pandemic. Molecular Plant, 13(8), 1095-1097.

Hocaoglu-Ozyigit, A., Ucar, B., Altay, V. ve Ozyigit, I. I. (2020). Genetic diversity and phylogenetic analyses of Turkish cotton (Gossypium birsutum L.) lines using ISSR markers and chloroplast trnL-F regions. Journal of Natural Fibers, 1-14.

ICTSD (2013). Cotton: Trends in Global Production, Trade and Policy; Information Note; International Centre for Trade and Sustainable Development, Geneva, Switzerland, ICTSD: 1-13.

Jin, L., Wang, J., Guan, F., Zhang, J., Yu, S., Liu, S., ... ve Wu, Y. (2018). Dominant point mutation in a tetraspanin gene associated with field-evolved resistance of cotton bollworm to transgenic $\mathrm{Bt}$ cotton. Proceedings of the National Academy of Sciences, 115(46), 11760-11765.

Kalkanc1, M. (2017). Sürdürülebilir tekstil üretiminde organik pamuk ve önemi. Academia Journal of Social Sciences, 1(3), 121-130.

Karnik, A. ve Lalvani, M. (1996). Interest groups, subsidies and public goods: Farm lobby in Indian agriculture. Economic and Political Weekly, 818-820.

Koondhar, M. A., Qiu, L., Liu, X., Abbassi, F., Koondhar, M. A. ve Ge, H. (2018). Effects of market price, cultivating area and price regulation on cotton production in China. African Journal of Agricultural Research, 13(16), 858-865.

Kranthi, K. R. ve Stone, G. D. (2020). Long-term impacts of Bt cotton in India. Nature Plants, 6(3), 188196.

Küçük, N. (2015). Pamuğun dünyası, küresel aktörler ve politikalar. ASSAM Uluslararası Hakemli Dergi, 2(4), 60-85.

Küçük, U. N. ve Iss1, S. (2019). Pamuk üretiminin stratejik önemi üzerine genel bir değerlendirme. TURAN: Stratejik, Arastirmalar Merkezi, 11(44), 391-398.

Laouan, A. M. (2021). Developed countries agricultural subsidies and cotton production in Burkina Faso: An analysis using the Vector Autoregressive Model (VAR). Modern Economy, 12(01), 46.

Lapegna, P. ve Perelmuter, T. (2020). Genetically modified crops and seed/food sovereignty in Argentina: scales and states in the contemporary food regime. The Journal of Peasant Studies, 1-20.

Li, N., Lin, H., Wang, T., Li, Y., Liu, Y., Chen, X. ve Hu, X. (2020). Impact of climate change on cotton growth and yields in Xinjiang, China. Field Crops Research, 247, 1-16, 107590.

Lioutas, E. D. ve Charatsari, C. (2021). Enhancing the ability of agriculture to cope with major crises or disasters: What the experience of COVID-19 teaches us. Agricultural Systems, 187, 103023.

Liu, B. ve Hudson, D. (2019). A preliminary analysis of the effects of China's cotton tariff on the Chinese and US cotton markets. Estey Journal of International Law and Trade Policy, 20(1753-2019-2986), 15-27.

Majumdar, G., Singh, S. B. ve Shukla, S. K. (2019). Seed production, harvesting, and ginning of cotton. In K. Jabran (Ed.), Cotton production (pp. 145-174). Wiley Online Library

Malcolm, S., Marshall, E., Aillery, M., Heisey, P., Livingston, M. ve Day-Rubenstein, K. (2012). Agricultural adaptation to a changing climate: economic and environmental implications vary by US region. USDA-ERS Economic Research Report, (136), 1-76.

Manc1, A. R. ve Binici, T. (2009). Türkiye'de organik pamuğun gelişimi. 1.GAP Tarım Kongresi, Şanlıurfa, 1-8.

Muhammad, A. ve Jones, K. G. (2021). The end of the trade war? Effects of tariff exclusions on U.S. forest products in China. Forest Policy and Economics, 122, 102350.

Munir, H., Rasul, F., Ahmad, A., Sajid, M., Ayub, S., Arif, M., ... ve Khan, M. A. (2020). Diverse Uses of Cotton: From Products to Byproducts. In S. Ahmad \& M. Hasanuzzaman (Eds.), Cotton production and uses (pp. 629-641). Springer, Singapore.

Ozyigit, I. I. (2009). In vitro shoot development from three different nodes of cotton (Gossypium birsutum L.). Notulae Botanicae Horti Agrobotanici Clij-Napoca, 37(1), 74-78.

Ozyigit, I. I. ve Gozukirmizi, N. (2008). High efficiency shoot and root formation from cotyledonary nodes of cotton (Gossypium birsutum L.). Pakistan Journal of Botany, 40, 1665-1672.

Ozyigit, I. I. ve Gozukirmizi, N. (2009). Efficient shoot and root formation from cotton shoot apices. Russian Journal of Plant Physiology, 56(4), 527-531.

Pan, D., Yang, J., Zhou, G. ve Kong, F. (2020). The influence of COVID-19 on agricultural economy and emergency mitigation measures in China: A text mining analysis. PloS One, 15(10), e0241167.

Paull, J. ve Hennig, B. (2019). New world map of genetically modified organism (GMO) agriculture: North and South America is 85\%. Acres Australia, 101, 59-60.

Qiu, J. (2010). GM crop use makes minor pests major problem. Nature, 1-2. 
Rauf, S., Shehzad, M., Al-Khayri, J. M., Imran, H. M. ve Noorka, I. R. (2019). Cotton (Gossypium birsutum L.) breeding strategies. In J. Al-Khayri, S. Jain \& Johnson, D. (Eds), Advances in plant breeding strategies: Industrial and food crops (pp. 29-59). Cham: Springer.

Rehman, A., Jingdong, L., Chandio, A. A., Hussain, I., Wagan, S. A. ve Memon, Q. U. A. (2019). Economic perspectives of cotton crop in Pakistan: A time series analysis (1970-2015) (Part 1). Journal of the Saudi Society of Agricultural Sciences, 18(1), 49-54.

Sharma, A., Kodgire, P. ve Kachhwaha, S. S. (2020). Investigation of ultrasound-assisted $\mathrm{KOH}$ and $\mathrm{CaO}$ catalyzed transesterification for biodiesel production from waste cotton-seed cooking oil: Process optimization and conversion rate evaluation. Journal of Cleaner Production, 120982.

Shera, P. S., Karmakar, P., Sharma, S. ve Sangha, K. S. (2018). Impact of Bt cotton expressing single (Cry1Ac) and dual toxins (Cry1Ac and Cry2Ab) on the fitness of the predator Chrysoperla zastrowi sillemi (Esben-Petersen): prey-mediated tri-trophic analysis. Egyptian Journal of Biological Pest Control, 28(1):98, 1-7.

Shirsath, P. B., Jat, M. L., McDonald, A. J., Srivastava, A. K., Craufurd, P., Rana, D. S., ... ve Jat, H. S. (2020). Agricultural labor, COVID-19, and potential implications for food security and air quality in the breadbasket of Hindistan. Agricultural Systems, 185, 102954, 1-8.

Sundar, K. ve Udayakumar, R. (2020). Comparative evaluation of the performance of rice bran and cotton seed biodiesel blends in VCR diesel engine. Energy Reports, 6, 795-801.

Şaşmaz, M. Ü. ve Özel, Ö. (2019). Tarım sektörüne sağlanan mali teşviklerin tarım sektörü gelişimi üzerindeki etkisi: Türkiye örneği. Dumlupınar Üniversitesi Sosyal Bilimler Dergisi, (61), 50-65.

Tokel, D., Genc, B. N. ve Ozyigit, I. I. (2021). Economic impacts of Bt (Bacillus thuringiensis) cotton. Journal of Natural Fibers, 1-18.

Ugurlu, M. (2020). Pamuk üretiminin ekonomik analizi: Manisa örneği. Ziraat Fakültesi Dergisi, 206-217.

Uras, M. E. (2021). In silico comparative analysis of SARS-CoV-2 nucleocapsid (N) protein using bioinformatics tools. Frontiers in Life Sciences and Related Technologies, 2(1), 1-9.

Voora, V., Larrea, C. ve Bermudez, S. (2020). Global Market Report: Cotton Sustainable Commodities Marketplace Series 2019 Series Editor: Sofia Baliño Sustannable Commodities Marketplace Series 2020, 1-16.

Wu, H., Zhang, X., Wu, B., Qian, C., Zhang, F., Wang, L., ... ve Wu, J. (2020). Rapid on-site detection of genetically modified soybean products by real-time loop-mediated isothermal amplification coupled with a designed portable amplifier. Food Chemistry, 126819, 1-7.

\section{YARARLANILAN LINKLER}

Alam, J. (2020). Bangladesh garment makers say $\$ 3$ billion in orders lost due to coronavirus. Time. Retrieved from: https://cupure. com/Bangladesh-Garment-Makers-Say-3-Billion-in-Orders-LostDue-to-Coronavirus.html

Globaltrademag, (2020). Agricultural Subsidies: Everyone's Doing It. Retrieved from: https://www.globaltrademag.com/agricultural-subsidies-everyones-doing-it/

Hazır Giyim (2020). IHKIB, Hazirgiyim ve konfeksiyon ihracatçları birliği, 2020 Ocak-Mart Hazırgiyim ve Konfeksiyon Sektörü İhracat Performans Değerlendirmesi, 1-54. Erişim adresi: https://www.itkib.org.tr/Home/KbDownload/konfeksiyon-Ihracat-degerlendirme-notu-agustos2020

ISAAA, (2019). International Service for the Acquisition of Agri-biotech Applications Biotech cropAnnual Update. Cotton. Published on Oct 30, 2019. Retrieved from: http://www.isaaa.org/resources/publications/biotech_crop_annual_update/download/biotechcrop-annual-update-cotton-2019.pdf.

Kelly, A. (2020). Primark and Matalan among retailers allegedly cancelling $f^{2}$.4bn orders in 'catastrophic' move for Bangladesh. The Guardian. Retrieved from https://www.theguardian.com/globaldevelopment/2020/apr/02/ fashion-brands-cancellations-of-24bn-orders-catastrophic-forbangladesh

Mordor Intelligence, (2018). Global cotton market - Segmented by geography - Growth, trends, and forecast (2019-2024). Retrieved from: https://www.mordorintelligence.com/industryreports/cotton-market

OECD Raporu (2020). Agricultural Policy Monitoring and Evaluation. Retrieved from: https://www.oecd-ilibrary.org/agriculture-and-food/agricultural-policy-monitoring-andevaluation_22217371 
Organic Cotton Market Report (2020). Covering production trends and initiative updates from the 2018/19 harvest year, Retrieved from: https://textileexchange.org/wpcontent/uploads/2020/08/Textile-Exchange_Organic-Cotton-Market-Report_2020-20200810.pdf

Pamuk Raporu (2020). T.C. Ticaret Bakanlı̆ğ Esnaf, Sanatkârlar ve Kooperatifçilik Genel Müdürlüğü, 2019 Yllı Pamuk Raporu, Nisan 2020, 1-40. Erişim adresi: http://www.upk.org.tr/User_Files/editor/file/2019\%20Pamuk\%20Raporu.pdf

Reuters (2021). U.S. bans imports of all cotton, tomato products from China's Xinjiang region. Published on Jan 13, 2021. Accessed on Feb 24, 2021. Retrieved from: https://www.reuters.com/article/ususa-trade-china-xinjiang-idUSKBN29I2KO

Seetharaman, G. (2020). How different sectors of the economy are bearing the brunt of the coronavirus outbreak. Retrieved from: https://economictimes.Hindistantimes.com/news/economy/policy/howdifferent-sectors-of-the-economy-are-bearing-the-brunt-of-the-coronavirusoutbreak/articleshow/74630297.cms

Tarım Orman (2020a). T. C. Tarım, Orman ve Köy İşleri Bakanlı̆̆ı Ürün Masalları, Kasım Bülteni, 1-57. Erişim https://www.tarimorman.gov.tr/BUGEM/Belgeler/M\%C4\%B0LL\%C4\%B0\%20TARIM/\%C3\%9 $\mathrm{Cr} \% \mathrm{C} 3 \% \mathrm{BCn} \% 20$ Masalar $\% \mathrm{C} 4 \% \mathrm{~B} 1 \% 20 \mathrm{Kas} \% \mathrm{C} 4 \% \mathrm{~B} 1 \mathrm{~m} \% 20 \mathrm{Ay} \% \mathrm{C} 4 \% \mathrm{~B} 1 \% 20 \mathrm{~B} \% \mathrm{C} 3 \% \mathrm{BClteni} / \mathrm{KAS}$ IM $\% 20 \mathrm{~B} \% \mathrm{C} 3 \% 9$ CLTENLER $\%$ C4\%B $\%$.pdf

Tarım Orman (2020b). T. C. Tarım ve Orman Bakanlığı, Konular, Bitkisel Üretim, Organik Tarım, Genel Bilgiler, Erişim adresi: https://www.tarimorman.gov.tr/Konular/Bitkisel-Uretim/OrganikTarim/Genel-Bilgiler

Tarım Orman (2020c). T. C. Tarım ve Orman Bakanlığı, Ürün Masalları, Pamuk Bülteni, Dünyada Pamuk, Erişim https://www.tarimorman.gov.tr/BUGEM/Belgeler/MILLI\%20TARIM/Ürün\%20Masalar1\%20Kas1 m\%20Ay1\%20Bülteni/Pamuk\%20Kasım\%20Bülteni.pdf

USDA (2020a). United States Department of Agriculture Foreign Agricultural Service, December 2020 Report, Cotton: World Markets and Trade, 1-28. Retrieved from: https:// downloads.usda.library.cornell.edu/usdaesmis/files/kp78gg36g/5m60rj41c/hh63tm60w/cotton_1_.pdf

USDA (2020b). United States Department of Agriculture. Agricultural Biotechnology AnnualPublished on February 2020.2 Retrieved from: https://apps.fas.usda.gov/newgainapi/api/Report/DownloadReportByFileName?fileName=Agricul tural\%20Biotechnology\%20Annual_New\%20Delhi_India_10-20-2019

USDA (2020c). United States Department of Agriculture. Cotton and Products Annual. Published on Apr 6, $2020 . \quad$ Retrieved from: https://apps.fas.usda.gov/newgainapi/api/Report/DownloadReportByFileName?fileName=Cotton $\% 20$ and $\% 20$ Products $\% 20$ Annual_Beijing_China $\% 20-\% 20$ Peoples $\% 20$ Republic $\% 20$ of_04-01-2020

USDA (2021). United States Department of Agriculture. Cotton: World Market and Trade. Published on Jan, 2021. Retrieved from: https://apps.fas.usda.gov/psdonline/circulars/cotton.pdf

\section{EXTENDED ABSTRACT}

Cotton is an important industrial plant that utilized as the raw materials in the textile, oil, feed, furniture, cellulose and paper industries as being used with its fiber, oil obtained from its seed, husk and pulp, and linter. With its wide utilization areas, cotton makes positive contributions on the development of the agriculture and industry of the regions and countries where it is grown. Rapid and uncontrolled population growth around the world increases the demand for cotton, as in all necessary requirements. This demand for cotton arises from the demands of the people's needs for dressing, nutrition as fat, and feed as used in animal husbandry. The latest data show that cotton fiber has a 35\% ratio in the all kinds of fibers used worldwide and is the most consumed fiber type in the textile plants. Although the consumption of artificial fibers is increasing rapidly, natural cotton retains its attractiveness because of people's preferences to use and the artificial fibers cannot replace natural cotton fiber usage. Looking at the worldwide cotton trade, as of 2020-21, several major producers including India, USA, China, Pakistan and Brazil realize about $70 \%$ of the total world exports.

When the recent data on cotton are examined, it is seen that cotton cultivation was carried out on an area of 34,840 thousand hectares in the world in 2019-20 and approximately $35 \%$ of this value $(13,300$ thousand ha) was realized in India. In 2020-21 period, this value was decreased to 32,510 thousand 
hectares. Cotton cultivation areas in 2020-21, produced (in thousand hectares) 13,400 in India, 3,640 in the USA, 3,250 in China, 2,200 in Pakistan and 1,550 in Brazil. Considering the world fiber cotton production data for the 2020-21 period, it is seen that the value of 25,929 thousand tons in the previous year decreased to 24,800 thousand tons. On a country basis, these values were (in thousand tons) 6,423 in India, 5,987 in China, 3,473 in the USA, 2,613 in Brazil and 980 in Pakistan. Until today, it is seen that the countries with the highest cotton production values are also the countries with the highest cotton consumption values worldwide. China is the country with the largest cotton consumption rate in the world with a value of $30 \%$, followed by India and Pakistan respectively. In the 2020-21 period, world cotton consumption increased from 22,219 thousand tons to 25,175 thousand tons in total, compared to the previous year, and ranking of the top three cotton consuming countries did not change. Considering the world cotton fiber yield $(\mathrm{Kg} / \mathrm{Ha})$ value of $2019-2020$ period, the first five countries were; Australia with 2,268, Brazil with 1,759, China with 1,720, Mexico with 1,519 and Turkey with 1,318, and this ranking changed as Australia with 1,900, China with 1,842, Turkey with 1,742, Brazil with 1,686 and Mexico with 1,429. The major cotton importing countries across the world were China, Bangladesh, Vietnam, Turkey and Pakistan for many years. In 2020-21 period, Turkey's rank was replaced with Pakistan and the general ranking became as; (in thousand tons) China 2,177, Bangladesh 1502, Vietnam 1,481, Pakistan 1,023 and Turkey 958. According to the data for the 2020-21 period, the total export in the world is 9,407 thousand tons and the top four countries in total exports are (in thousand tons) the USA (3,266), Brazil $(2,177)$, India $(1,089)$ and Greece $(283)$. Considering the data of cotton prices, it was seen that cotton prices had generally followed a lower trend compared to previous years, although the world cotton prices were increased up to 1.92 dollars per $\mathrm{kg}$ in 2019. In the period of 2020-21, large producer and consumer countries have tended to reduce the world cotton prices in order to stop the negative effects of the Covid-19 pandemic on the cotton market. Nevertheless, the prices increased due to the decrease in production as a result of unfavorable weather conditions in the USA, followed by high cotton demands from China, Bangladesh, Vietnam and Pakistan.

As it is known, organic cotton production is an important issue for the cotton markets worldwide. When the data of organic cotton production is analyzed, it is seen that most of the global organic cotton $(97 \%)$ is produced by the following countries today: India (51\%), China (17\%), Turkey (10\%), Kyrgyzstan $(10 \%)$, Tajikistan $(5 \%)$, Tanzania $(2 \%)$ and the USA $(2 \%)$. The remaining $3 \%$ is Uganda $(1.08 \%)$, Greece $(0.49 \%)$, Benin $(0.42 \%)$, Peru $(0.23 \%)$, Burkina Faso $(0.19 \%)$, Pakistan $(0.17 \%)$, Egypt $(0.12 \%)$ Ethiopia $(0.05 \%)$, Brazil $(0.04 \%)$, Mali $(0.03 \%)$, Argentina $(0.005 \%)$ and Thailand $(0.003 \%)$. Organic cotton was produced by 19 countries in 2018-2019 periods. Regarding the production of transgenic cotton, an application that can be said the opposite of organic cotton, cotton plant became one of the first four genetically modified crops grown in the world, and in recent years, there has been a large increase in worldwide GM cotton cultivation areas.

Covid-19 pandemic has been a major problem worldwide in 2020, and the negative impacts of this pandemic is expected to be continue in 2021. Cotton prices, which had risen before the pandemic, reduced sharply from January to April. Afterwards, prices increased as a result of factory use and other factors supported the recent strengthening in the market. Later on, many factories and commercial companies have been closed due to the public health directives that caused cancellation and/or suspension of existing orders in western clothing brands. As of December 2020, sharp decline in production in Pakistan, India and Australia was partially balanced by the increase in Turkmenistan. Consumption increased in India, China and Pakistan, but on the contrary, decreased in Thailand. On the other hand, global trade tended to increase slightly in Bangladesh and Thailand. It is estimated that there will be a reduced production and increased exports in the USA in the advancing period. 